\title{
Free Flow or Morality Bought: On the Construction of Remittances as an Object of Study
}

\author{
Olav Eggebø \\ Research fellow at the Norwegian University of Science and Technology. E-mail: olav.eggebo@svt.ntnu.no
}

Received: August, 2010 / Accepted: September, 2010

ThIS ARTICLE DESCRIBES HOW REMITTANCES HAVE BEEN REPRESENTED in social scientific texts. Social scientists have predominantly linked discussions about remittances to discussions about development, and many observations regarding remittances have been put into theoretical models where their main purpose has been to verify those models of thought. Remittances have been presented as significant because of the instrumental effects they have for the economy, the society and/or the political system. In this way, discourses on remittances can illuminate not only views on remittances, they can also illuminate intrinsic views of how the world should look like.

Remittances have merely been considered in the light of macro models and systems theory, detached from the persons that are in fact the senders and receivers of this money. In this article it is argued that these remittances should not be considered in an instrumental way. The "flow" of remittances is significantly regulated and sanctioned by moral representations linked to structures like household, family and gender. The transactions are manifestations of the personal relations between the actors of the transaction, and cannot be reduced into a model that treats the actors as isolated individuals.

Key words: Remittances / Transactions-Actors / Personal Relations

\section{Libre flujo o moralidad comprada: la construcción de las remesas como objeto de estudio}

El artículo describe cómo las remesas han sido presentadas en textos de ciencias sociales. Los cientistas sociales, de forma reiterada, han vinculado las discusiones sobre remesas con discusiones sobre desarrollo. Muchas observaciones sobre las remesas se han planteado en el marco de modelos teóricos cuyo propósito principal ha sido verificar esos mismos modelos de pensamiento. Las remesas se han presentado como algo significativo por sus efectos instrumentales en la economía, la sociedad y/o el sistema político. De esta manera, los discursos sobre remesas 
pueden revelar tanto la percepción que se tiene sobre las remesas como los puntos de vista intrínsecos sobre cómo debería de ser el mundo.

Las remesas han sido consideradas a la luz de modelos macro y la teoría de sistemas. De esta manera, han sido desvinculadas de las personas que son, de hecho, quienes envían y reciben este dinero. En este artículo se argumenta contra el análisis instrumental de las remesas. El "flujo" de las remesas es regulado y aprobado de manera significativa por representaciones morales vinculadas a estructuras como el hogar, la familia y el género. Las transacciones son manifestaciones de las relaciones personales que existen entre los actores de la transacción y no pueden ser reducidas a un modelo que trata a los actores como individuos aislados

Palabras clave: remesas / transacciones-actores / relaciones personales

Lillian left Estelí and moved to Miami when her husband lost his job because of alcoholism.

"When my husband got fired, I didn't see any other option. I could not let my children go hungry.

I feel it was my duty as a mother that made me leave".

Lillian started to send money the first week in Miami, and a good portion of her salary went back to Nicaragua. Back home in Estelí her husband continued to drink, and Lillian found it harder and harder to accept that the remittances financed her husband's alcoholism.

“(...) when my oldest daughter finished high school (secundaria) I decided that the kids should move out from their father's house. My brother helped me and found them a house where they could live. Now they are living by themselves and they have very little contact with their father"

The first year in Miami, Lillian continued to send money to her husband, but after the kids moved out she started sending the remittances to her oldest daughter instead. The remittances are paying the rent of the house and their other expenses.

"Legally we are still married, but one day we have to make our "break up" formal. I expect that we have to sit down together with our lawyers and it's going to be a fight. He is going to argue that I left my own children in Nicaragua to live the good life here in Miami. So I have to be prepared (...),

Lillian then showed me a bag filled with all her Western Union receipts for her entire stay in Miami.

"One lady I met here in Miami told me what happened in her divorce law suit and she recommended me to keep all the proof for my support, and I have kept

receipts for every single dollar I have sent. When he accuses me of having neglected my obligations as a mother am I going to show them to both him and the lawyers."

Lillian was sending money from Miami to Estelí, but her sending of remittances between Miami and Estelí cannot be understood as purely monetary transactions, even if it was money that was being sent. In this article I will argue that these remittances should not be considered in an instrumental way. I will return to Lillian's story after I have shown how remittances have been represented by social scientists.

\section{Remittances}

Every day, migrants working in rich countries send money to their families in the developing world. It's just a few hundred dollars here, a few hundred dollars there. But last year, these remittances added up to $\$ 80$ billion, outstripping foreign aid and ranking as one of the biggest sources of foreign exchange for poor countries (Kapur \& McHale, 2003, p.49). 
In its simplest form, remittances can be defined as the goods or money sent home by migrants. As Kapur and McHale wrote, "It's just a few hundred dollars here, a few hundred dollars there", but when social scientists write about these transactions, they have been given a name and have been constructed as a scientific object with certain qualities and properties.

In this article I will analyze how remittances are constructed as an object of study in the social sciences, and connect these different modes of describing remittances to larger theoretical and political discourses intrinsic in these descriptions.

The awareness of the construction of remittances as an object of study is of great importance in my PhD project of the impact of remittances in Estelí, Nicaragua. And these reflections on remittances have in a large part been triggered by my fieldwork in Estelí and Miami.

\section{Creating the objects of study}

Nietzsche was contemptuous of concept formation, which in his opinion violates the primordial and unmediated experience of individual man. A word becomes a concept insofar as it simultaneously has to fit countless more or less similar cases, cases which are never equal. Every concept arises from the equalizing of disparate things, stated Nietzsche (Nietzsche, 1876). I am not going to be as distrustful regarding concept formation as Nietzsche, but it is crucial to be conscious of how a few hundred dollars here, a few hundred dollars there becomes an entity that is being depicted as one of the most important factors for poor countries.

Bourdieu shows how scientific research is now organized around constructed objects that no longer have anything to do with the units divided up by native perception (Bourdieu, Chamboreon \& Passeron, 1991). And none of these objects of study exist an sich:

One has to be aware that every distinctive scientific object is consciously and methodically constructed, in order to know how to construct the object and to know what it is one has constructed; and all this has to be known in order to reflect on the techniques for the constructing of the questions to be put to the object (Bourdieu et al., 1991, p.49).

To be able to describe and discuss complex social scientific topics, some kind of objectifying seems to be necessary (Bourdieu et al., 1991, p.50). The need to construct specific labels which in turn construct new objects by constructing new relationships between aspects of things are, as Bourdieu claims, the first degree of the epistemological break with the preconstructed objects of spontaneous sociology. Social scientific practice involves the process of de-trivialization of what is taken for granted, to make a break or a rupture from the representations, questions and problem formulations of common-sense understandings, a break with "pre-notions" and "pre-concepts", and to develop instead an autonomous object area which has systematic foundations and which formulates its own questions (Bourdieu et al., 1991). 
Even the most elementary and automatic collection of information involves epistemological choices and a theory of the object. To be able to ask the right questions and use the right research techniques we need to construct the objects of study, while it is simultaneously important to know that any construction of an object is never without any intrinsic impetus. Although the objects are constructed, and not naturally given, they are not random. This process of object construction is not happening tabula rasa and an approach to how objects are being constructed can give us a higher awareness of the predispositions in and of social science.

\subsection{Self awareness as a social scientist}

What we call “descriptions" are instruments for particular uses. Ludwig Wittgenstein

In all forms of academic enquiry, theories frame questions, and such theories may be both implicit and explicit. They are also embedded in analytic terms, like remittances. All social scientists, regardless of whether they study remittances or not, must therefore take themselves as an object. To use its own weapons and techniques to understand and check itself to increase its chances of attaining truth by increasing the cross-controls and provide the principles of a technical critique, which make it possible to keep closer watch of the factors capable of biasing research (Bourdieu, 2004). According to Bourdieu, the social scientists level of consciousness to the theory engaged in practice is decisive for the outcome of the research. The lack of theoretical consciousness, that means the lack of theory of the knowledge of the object and the theory of the object will make the research process less controlled, and less adapted to the specific objects (Bourdieu et al., 1991). The sociologists are subjects to the ebbs and flows of the "zeitgeist", they carry ways of thinking and prejudices that they owe to their social origin, the social position they have acquired, and their specific roles as intellectuals, but also to the social order within their own scientific community and their positions within it (Bourdieu, 2004).

The analyses of how remittances have been constructed as an object of study both assess and help define remitting. Moreover, the analysis of how remittances are represented can shed some light on the epistemologies and politics embedded in these descriptions. For example, remittances are positioned and repositioned in relation to other sources of currency, other forms of income, other strategies for development, etc. In showing how these representations are presented, I hope to illuminate not only remitting itself, but also how epistemological choices and theories of the object arise out of larger political and theoretical discourses.

\section{Intrinsic politics in the social sciences on remittances}

To approach the conceptual interconnections of problems in social science is a way to pinpoint the intrinsic politics of the scholar's descriptions of social matters. This can also be a way of better understanding descriptions of remittances and the impacts of remittances. As Henrietta Moore writes about anthropologists' approach to globalization: 
Critics have pointed out that much anthropological writing invokes notions of the global or globalization, rather than empirically analyzing them. The result is ethnography situated within an imagined, if not imaginary, global context or studies of globalized processes that lack ethnographic detail, the texture of lives lived and identities constructed (Moore, 2004, p.72).

Remittances have been situated within a more or less imagined global context and much of the differential views on remittances can be traced to the different ways the global context has been understood. These different ways of imagining the global can, in turn, be traced to different ideological positions.

\subsection{Dependency theorists: - Remittances create underdevelopment}

The first representations of remittances in Latin America were primarily pessimistic. Social scientist linked remittances and the impacts of remittances to processes that created and maintained underdevelopment. Text inspired by dependency theory and world-system theory described the negative effects emigration has for Latin American societies (Reichert, 1981; Wiest, 1984). The arguments were mainly that Latin-American countries became eroded and impoverished because of the outward migration of Latin American youth who leave their homes to sell their labour-force in the USA or Europe. Talented Latin Americans leave their home countries to work as low-skilled workers in the rich world instead of creating a career for themselves in Latin America. Even if remittances can relieve some of the "underdeveloped" countries' symptoms, they are not solving the cause of the problem (Reichert 1981). Work migration is thus seen as a short-sighted defensive strategy that maintains the social and economical differences between the countries (Reichert, 1981).

Dependency and world-system theory were in many ways paradigmatic in social scientist analyses of Latin America during the 1970's and 1980's (Archetti \& Stølen, 1996). It was very easy for social scientists to pinpoint the bad impacts of remittances using dependency or world-system theory. The basis of these theories is that poor nations are at a disadvantage in their market interactions with wealthy nations. Dependency theorists argued, in opposition to free market economists, that underdeveloped countries needed to reduce their connectedness with the world market so that they could pursue a path more in keeping with their own needs, less dictated by external pressures (Nustad, 2003). Remittances were sent by Latin-American emigrants that sold their labour force abroad, and the emigrants were considered as victims of the push-pull factors that produced the exodus (Fuglerud, 2001). In this manner, remittances became proof of the disadvantaged position of the poor nations market interactions with wealthy nations.

There are several ways to question these assumptions. First, the predominant focus on nations and systems. Emigrants and receivers of remittances in these studies became reduced to parts of an exchange between nations. The transactions are not merely seen as a contribution from a daughter to her mother or contribution from a husband to his wife, they are seen as foreign capital entering the nation.

Inserting the nation into this exchange suggests that, much like exported coffee, exported workers have national essences (Hernández \& Coutin, 2006). Migrant labour is nationalized 
through the claim that nations "own" the labour of their citizens. As the next paragraph shows, emigration is considered a marked exchange of people's qualities.

If highly skilled migrants are more likely to establish permanent ties abroad and less likely to remit funds home, or to remit smaller amounts, then sending countries experience a double deprivation: not only do they lose valuable human capital; they do not receive a return flow of capital to compensate the loss (Taylor, Arango, Graeme, Kouaouci, Massey \& Pellegrino, 1996, pp.192-193).

Claiming remittances as a national resource nationalizes migrant labour in several ways. First, labour is treated as an export, akin to other national products, and remittances then become the return that nations receive in exchange for exporting labour (Hernández \& Coutin 2006)

\section{2. (Neo)Liberal scholars: - Remittances create development}

More recently we have seen that the image of remittances and the impact of remittances have changed. From the late eighties many economists, social scientists and politicians have started to look upon remittances with excitement and not so little optimism. Descriptions of how migradollars have created positive effects in poor countries became more and more common as the amount of dollars being remitted rose (Massey, Goldring \& Durand, 1994; Jones, 1992). Remittances were considered more important for the daily life of Latin Americans, and according to many social scientists, quite a few countries (like El Salvador, Mexico and Nicaragua) changed from being agro export economies to being labour exporting economies (Orozco, 2005). The emphasis of these scholars was put on the money coming into the national economies, and the more money coming in, the better.

Remittances were considered to be national yet foreign, and even if these transactions were sent with a specific address, these dollars were seen as a very important part of the "trickledown economy" and other industries were being fuelled by this new kind of foreign capital (Orozco, 2005). Remittances began to be compared with foreign aid, and when numbers from the World Bank and Inter American Development bank revealed that the amount of remittances exceeded foreign aid, some social scientists and politicians began talking about remittances as the poor worlds' hope:

Unlike other sources of foreign exchange, Migradollars flow directly to the people who need them the most, without being filtered through intervening social and economic structures... The $\$ 2$ billion sent by poor migrants working in the United states goes directly to households at the bottom of Mexico`s economic pyramid (Durand \& Massey, 1992, p.441).

The excitements regarding remittances' positive impact arose in a particular context: namely the late twentieth-century debt and currency crises that in turn provoked structural adjustment programmes on the part of poorer nations. Foreign currency -particularly strong currencies like US dollars-, became a scarce commodity during the $1980 \mathrm{~s}$, as poor nations reeled from the effects of deep indebtedness. This context gave remittances new visibility and 
a national yet foreign character, as the return on a national product and as a gift from other nations (Tsing, 2000). The money seems to come from out of the blue. Somewhat magically remittances are extradited from the other regimes of value within which they circulate and are rid of their prior associations. Through financial "conjuring", transactions between family members are "opened up" to global finance (Tsing, 2000). Comparing remittances to foreign aid suggests that this currency simply arrives (Hernández \& Coutin, 2006).

\subsection{Globalization critics: - Remittances create inequality}

Other social scientists were more or less making the opposite argument using the same numbers (Robinson, 2001; Binford, 2003). They showed how remittances were a part of the neoliberal destruction of the Latin American societies. Structural adjustment programmes contributed to increased migration, as social services were cut (Ong, 1987). Even if the flow of remittances leads more hard currency into the national economies, remittances created larger class differences, not more development. Remitting practices were seen as creating more individual-based societies where people with access to migradollars became better equipped for upward mobility through their economic possibilities to use private schools and hospitals. In this manner, a bigger difference between those who could afford high quality health care and education and those who could not, was created.

Scholars like Leigh Binford also started to focus on productive ways to use remittances, by distinguishing between remittances as consumption and remittances as investment. Binford argued that the inherent developmental qualities that remittances possess were limited by some remittances receivers' conspicuous consumption (Binford, 2003). Instead of creating more productive investment, new jobs and productivity, the flow of remittances are creating a US consumer pattern where in the end only the big companies like Coca Cola, American Airlines and Wall Mart are gaining any real profit.

Scholars like Leigh Binford show a tendency to focus on nations and systems by viewing remittances as something that flows between nation states and not between people. When Binford talks about productive ways to use remittances and encourages the poor to use remittances in ways that benefit national economies, it is easy to conclude that debates over remittances' effects are themselves forms of morality and governmentality.

Binford's argument also illustrates how discourses on remittances can illuminate intrinsic views of how the world should look like. Jeffery Cohen and colleagues have written a collective response to Binford's arguments:

If remittances "merely" enable Latin-American migrant families to survive, build homes, live in retirement and invest in a few simple businesses, and this is bad, then we are left to wonder what kind of utopian "miracle solutions" Binford would envision for such places that would turn them into economic dynamos (Cohen, Jones \& Conway, 2005). 


\section{Politics on remittances}

Discourses on remittances have been a part of the political scene for almost as long as remittances have been a topic in the social sciences. Some typical receiver nation-states have used the perceived amount of remittances as a security for international loans and typical sender countries have used their immigration laws in a pragmatic way to regulate the flow of remittances.

After the devastating earthquakes in El Salvador, 2001, and in Haiti, 2010, the US government gave Salvadorians and Haitians a "Temporary Protected Status" (TPS) enabling "illegal" immigrants from these two countries, by giving them a temporary visa and a working permit in the USA, to send more money to the earthquake victims (Hernández \& Coutin, 2006; Miami Herald, October, 20, 2010).

During a March 2001 interview, a US embassy official confirmed that migrant remittances were considered part of the assistance the USA gave to El Salvador:

That's right, TPS is part of the foreign aid packet: and I think that TPS is going to be beyond what they are receiving through other forms of assistance that are being provided. It's the most important thing that we could have done (Hernández \& Coutin, 2006).

The US government has actively used these TPS to play an active part in determining the "deserving" receivers of remittances. In 2010, the US government decided that 200,000 Haitian migrants could file for Temporary Protected Status (Miami Herald, February, 20, 2010).

\section{Models and instrumental effects}

In all the above-mentioned representations, remittances are significant because of the instrumental effects they have for the economy, the society and/or the political system. Remittances have merely been considered in the light of macro models and systems theory, yet detached from the persons that are in fact the senders and receivers of this money. This predominantly instrumental focus has caused the Nicaraguan philosopher Jose Luis Rocha to speculate:

Nobody even considers giving a special name to income received from selling alcoholic beverages or suggests reinvesting it in community parks. What's so special about these gifts from relatives abroad that isn't shared by gifts from relatives living inside the country? Are the US\$70, $\$ 100$ or $\$ 200$ that a family gets from abroad automatically more productive than the $\$ 300$ earned by a small-scale coffee farmer? In short, why so much fuss about remittances? It would appear that the money labelled "remittances" is more public, more manipulable, so everyone wants a say about its current or potential uses (Rocha, 2008). 
I am asking the same question as Rocha; why so much fuss about remittances? Why do the hundred dollars here, and hundred dollars there, possess bigger symbolic, political and social properties than other transactions, and why should we group all these transactions into one big object of study that produces some specific kind of societal consequences?

\section{Entification}

Remittances have in these above-mentioned studies been constructed as different kinds of objects of study, but a similarity in all these examples is that remittances have been seen as an instrumental part of economic, political and social scientific models. In such models, concepts are treated as entities that have object qualities that can be related in some way or another and therefore produce a specific kind of consequence.

Objectification or entification opens up a gap between individual actions and its properties, which exist at a distance from the acting and choosing person. Entification is a prerequisite for social science, but it is also a prerequisite for management and governmentality. As the demand for management increases, so does the number of manageable entities (Larsen, 2010, p.231). When we are giving the economic transactions from emigrants to their family and friends at home a special name, we make it possible to compare remittances to other sources of currency, other forms of income, other strategies for development, etc. As these are comparable, they are also different from other economic objects, and will cause different effects on the economic system than other entities, such as exports and foreign aid, which also are significant instrumental entities of economic models.

\section{The Nation State model and Globalization theory}

One central and defining attribute or quality of the entity remittance is that it is an external factor. It is being treated differently from other "natural" entities of the nation state economy because its origin is external. Because of this, the individual household-based economic transactions become manipulable, and disappoint scholars like Binford when they do not produce the right kind of consequences. As an external force, remittances are given different symbolic and instrumental properties than domestic transactions. The qualitative change projected on to the money as it crosses the bureaucratic nation state borders, is leading to a reification of the naturalness of the same bureaucratic boundaries.

This reification of the naturalness of the borders through unconscious treatment of the objects of study can be found not only in studies of remittances. Much of the focus on migration and the focus on the movements of individuals between one nation state to another seems to extend the traditional mode of treating people and societies, more than many social scientist are aware of. The concept of migration and the focus this concept implies directs the investigations. It is predominantly limited by the presupposition of the self evident existence of the National-States. Hence, immigration studies contribute to the fixation of one distinct political order: the National-State model (Krohn-Hansen, 2005; Røyrvik \& Eggebø, 2010). 
One of the main underlying difficulties with descriptions of remittances is the dual nature of remittances as both national and foreign. To describe remittances this way it is necessary to understand the relations between senders and receivers of remittances by using theories about global interconnections. In many cases, the link between theory and observation is very strong. The existing ontology and epistemology and not least the political order are decisive factors in both the observations and the conceptual interconnections of these observations. Numerous observations regarding remittances have been put into a theoretical model and their main purpose has been to verify that model of thought. It is on this basis that scholars like Henrietta Moore have argued that the global and the local are no more than heuristic devises, and therefore do not exist as empirical realities; they are contexts for making sense of data, experiences and processes - both for social scientists and for their subjects (Moore, 2004). This might be seen more clearly among scholars who write about development than among others. Texts, of the likes of the dependency theorist Reichert, the liberal economist Orozco and the globalization critic Binford, clearly resemble each other in that their underlying theories on global interconnections are more than just contexts of making sense of data, they are also guidelines for how the world should look like.

\section{Social relations and everyday life}

En Western Union sabemos que le estás enviando a tu familia mucho más que dinero... Western Union commercial

As mentioned above, remittances seem to be the result of individual or household-level decisions, yet they are treated as both national resources and as foreign donations (Hernández \& Coutin, 2006). Many of the social scientific texts about this topic are lacking ethnographic detail, the texture of lives lived and identities constructed (Moore, 2004). The theories embedded in many of the descriptions are not very subtle and individuals are being given importance mostly as aggregates of their collective or semi collective behaviours.

As Western Union is quite aware of, migrants are sending much more than money. I find it important to not see remittances as detached from the social relations they are a part of. Instead of seeing the remittances in a pure sender-receiver model, I will consider these types of transactions as part of a reciprocal relation. There is no such thing as a free gift, as gifts materialize social relations. The transactions are manifestations of the personal relations between the actors of the transaction, and cannot be reduced into a model that treats the actors as isolated individuals. In my study I will ascend from these social relations to wider aspects of social and economical life. I am locating this exchange within socio cultural relationships and will try to use the insight that gift/remitting grants to get a better insight into the broader economy and culture.

This study is clearly at some level a study of transnational flow of capital, but I want to study these transactions without losing track of the people that are actually making the money flow. The senders and the receivers of these remittances are acting, choosing people that are concerned about their social being as well as their future in their native place (Sahlins, 1999). People living in poverty, or people trying to escape poverty, are not merely parts of 
the developmental process of their nations, and the nations' developments are not their main motivation for action. Neither the senders nor the receivers of these transactions are national citizens first, and social beings second. And as I have mentioned above, quite few scholars have ignored the social aspects of these transactions when they have constructed remittances as an object of study. And it seems that topics like obligations and morality have been stripped away from the concept to make it easier to put them into the economical equation.

During my fieldwork in Estelí and Miami, I perceived a clear tendency that narratives on remittances are very often narratives on moral, and according to my informants, the "flow" of remittances is significantly regulated and sanctioned by moral representations linked to structures like household, family and gender. One of my main interests of study is thus, how morality is part of the channelling of these transactions.

The story of Lillian that opened this article sheds some light on the "power" or control the remittances-senders can have over the receivers, but at the same time it tells us how the power and control can go both ways. Lillian kept all her receipts because she knew that one day she was going to defend herself and she needs hard evidence to prove that she has kept her obligations. She was able to decide the address of the remittances but in changing receivers of her gift she put herself under a more thorough moral scrutiny. Lillian left Nicaragua, but she did not leave her moral obligations as a mother. These obligations were very important for Lillian as a social being, and this story is similar to many others.

Lillian's story illustrates the importance of including how remittances are embedded in social relationships because this story illustrates the gap between the way remittances are seen as an object of study and the lived experience of the actual actors. Existing social relations are channeling the addresses and the quantum of remittances, and as we saw in Lillian's case, remittances can both maintain and disrupt social relationships. Stories like Lillian's can also show the usefulness of ethnography contra pure statistics. Some macro oriented social scientists are just observing how a few hundred dollars here, and a few hundred dollars there cross national borders and then add them up, without paying attention to how and why the money is changing hands.

\section{References}

Archetti, E. \& Stølen, K. (1996). Latin-Amerika. In S. Howell \& M. Melhuus (Ed.) Fjern og ncer: sosialantropologiske perspektiver på verdens samfunn og kulturer, Oslo: Gyldendal.

Binford, L. (2003). Migrant Remittances and (Under)Development in Mexico. Critique of Anthropology, 23 (3), 305-336.

Bourdieu, P., Chamboreon, J. C. \& Passeron, J. C. (1991). The Craft of Sociology: Epistemological Preliminaries. Berlin, New York: Walter de Gruyter.

Bourdieu, P. (2004). Science of Science and Reflexivity. Chicago: Polity Press.

Cohen, J., Jones, R. \& Conway, D. (2005). Why Remittances Shouldn`t Be Blamed for Rural Underdevelopment in Mexico: A Collective Response to Leigh Binford. Critique of 
Anthropology, 25 (1), 87-96.

Durand, J. \& Massey, D. (1992). Mexican migration to the United States: a critical review. Latin American Research Review, 27(2), 3 /42.

Fuglerud, Ø. (2001). Migrasjonsforståelse: Flytteprosesser, rasisme og globalisering. Oslo: Universitetsforlaget

Hernández, E. \& Coutin, S. (2006). Remitting Subjects: Migrants, Money and States. Economy and Society, 35 (2), 185-208.

Jones, R. (1992). US Migration: An Alternative Economic Mobility Ladder for Rural Central Mexico. Social Science Quarterly, 73, (3), 496-510.

Kapur, D. \& McHale, J. (2003). Migration`s new payoff. Foreign Policy, Nov/Dec, 49-57.

Kron-Hansen, C. (2005). Dominikanere i New York og forståelsen av migrasjon. Norsk Antropologisk Tidsskrift (The Journal of the Norwegian Association of Social Anthropologists), 16 (2-3), 75-84.

Larsen, T. (2010). Acts of Entification: The Emergence of Thinghood in Social Life. In N. Rapport (Ed.). Human Nature as Capacity, An Ethnographic Approach. Berghahn.

Massey, D., Goldring, L. \& Durand, J. (1994). Continuities inTransnational Migration: An Analysis of Nineteen Mexican Communities. American Journal of Sociology, 99 (6), 1492-1533.

Moore, H. (2004). Global Anxieties: Concept-Metaphors and Pre-Theoretical Commitments in Anthropology. Anthropological Theory, 4 (1), 71-88.

Nietzsche, F. (1876 [trans. 1996]). Human, All Too Human. R. J. Hollingdale. Cambridge: Cambridge University Press.

Nustad, K. (2003). Gavens makt, Norsk utviklingshjelp som formynderskap. Oslo: Pax.

Ong, A. (1987). Spirits of Resistance and Capitalist Discipline: Factory Women in Malaysia. Albany: State University of New York Press.

Orozco, M. (2005). Transnationalism and Development: Trends and Opportunities in Latin America. In S. Muzele Maimbo (Ed.). Remittances: Development Impact and Future Prospects, USA: World Bank.

Robinson, W. I. (2001). Transnational Processes, Development Studies, and Changing Social Hierarchies in the World System; A Central American Case Study. The Third World Quarterly, 22 (4), 529-563.

Røyrvik, J. \& Eggebø, O. (2010). Penguins or sparrows? What we talk about when we talk about migration. iNtergraph: journal of dialogic anthropology,2.

Sahlins, M. (1999). What is Anthropological Enlightenment? Some Lessons of the Twentieth Century. Annual Review of Anthropology, 28, i-xxiii.

Taylor, J. E., Arango, J., Graeme, H., Kouaouci, A., Massey, D. \& Pellegrino, A. (1996). International migration and national development. Population Index, 62 (2), 181-212.

Tsing, A. (2000). Inside the economy of appearances. Public Culture, 12 (1), 115-144.

Reichert, J. (1981). The Migration Syndrome: Seasonal US Wage Labour and Rural Development in Central Mexico. Human Organization, 40 (1), 56-66.

Rocha, J. L. (2008). Central America: Remittances Are Far More Than A Development Panacea”, Revista Envío (320), marzo. Retrieved on July 1, 2010 from http://www.envio. org.ni/articulo/3733

Wiest, R. (1984). External Dependency and the Perpetuation of Temporary Migration to The United States. In R.C. Jones (Ed.). Patterns of Undocumented Migration: Mexico and The United States. Tottawa: Rowman and Littlefield. 